\title{
Biological Control of the Weed Sesbania exaltata Using a Microsclerotia Formulation of the Bioherbicide Colletotrichum truncatum
}

\author{
Clyde D. Boyette ${ }^{*}$, Hamed K. Abbas' ${ }^{1}$, Bobbie Johnson', Robert E. Hoagland², \\ Mark A. Weaver ${ }^{1}$ \\ ${ }^{1}$ United States Department of Agriculture-Agricultural Research Service (USDA-ARS), Biological Control of Pests \\ Research Unit, Stoneville, MS, USA \\ ${ }^{2}$ United States Department of Agriculture-Agricultural Research Service (USDA-ARS), Crop Production Systems \\ Research Unit, Stoneville, MS, USA \\ Email: ${ }^{*}$ doug.boyette@ars.usda.gov
}

Received 23 May 2014; revised 12 July 2014; accepted 5 August 2014

Copyright (C) 2014 by authors and Scientific Research Publishing Inc.

This work is licensed under the Creative Commons Attribution International License (CC BY).

http://creativecommons.org/licenses/by/4.0/

(c) (i) Open Access

\begin{abstract}
Colletotrichum truncatum, grown on rice grain ( 3 to 4 weeks, $22^{\circ} \mathrm{C}$ to $24^{\circ} \mathrm{C}$ ) produced a fungus-infested rice mixture of microsclerotia and conidia (spores) in a ratio of $\sim 9: 1$, respectively. Greenhouse tests of this formulation (0.4 to $50 \mathrm{mg}$ finely-ground fungus-rice product) which applied pre-emergence to $5 \mathrm{~cm}^{2}$ of soil surface, caused $22 \%$ to $96 \%$ hemp sesbania plant mortality, after 14 days. Post-emergence treatment (fungus-rice aqueous formulation; $2.4 \times 10^{5}$ microsclerotia $\mathrm{ml}^{-1}, 30 \%$ unrefined corn oil and $0.2 \%$ Silwet L-77 surfactant) of weeds surviving the pre-emergence application, resulted in $93 \%$ mortality, after 14 days. Based on greenhouse results, field tests were undertaken: 1) pre-emergence treatment (fungus-rice formulation at $2.4 \times 10^{5}$ microsclerotia $\mathrm{cm}^{-2}$ ), 2) post-emergence (fungus-rice product in $30 \%$ unrefined corn oil, $0.2 \%$ Silwet) only treatment, applied 15 days after planting and 3) pre-emergence treatment followed by post-emergence treatment (fungus-rice product in 30\% unrefined corn oil, $0.2 \%$ Silwet) applied 15 days after planting to surviving weeds. Control treatments were: 1) autoclaved rice product sans fungus, 2) unrefined corn oil (30\% unrefined corn oil, $0.2 \%$ Silwet in water) and 3 ) untreated plants. Planting dates were: early season (April-May), early-mid season (June-July), late-mid season (July-August), and late season (September-October). Weed mortality was recorded at 15 days for the pre-plus post-treatment, and at $\mathbf{3 0}$ days after planting for the pre-emergence only and the post-treatment only. The early season, pre-emergence treatment caused $67 \%$ hemp sesbania mortality (3-yr average) within 15 days and the post-emergence treatment caused $91 \%$ mortality of the surviving weeds. In the late-mid-season, pre-emergence treatment caused minimal $(<5 \%)$

${ }^{*}$ Corresponding author.
\end{abstract}

How to cite this paper: Boyette, C.D., Abbas, H.K., Johnson, B., Hoagland, R.E. and Weaver, M.A. (2014) Biological Control of the Weed Sesbania exaltata Using a Microsclerotia Formulation of the Bioherbicide Colletotrichum truncatum. American Journal of Plant Sciences, 5, 2672-2685. http://dx.doi.org/10.4236/ajps.2014.518282 
mortality at 15 days, but mortality in the post-emergence treatment was $>\mathbf{8 0} \%$. Results suggest that seasonal environmental conditions are important in the efficacy of this $C$. truncatum-rice product formulation when applied pre- or post-emergence to this onerous weed.

\title{
Keywords
}

\author{
Bioherbicide, Biological Weed Control, Colletotrichum truncatum, Mycoherbicide, Sesbania \\ exaltata, Microsclerotia, Solid Growth Media Substrate
}

\section{Introduction}

Concerns regarding environmental contamination, food safety, and the evolution of herbicide-resistant weeds, brought about by the use of chemical herbicides, have culminated in the need for alternative weed management tools and strategies. Phytopathogenic fungi and bacteria that attack and infect weeds have been used inundatively as weed control agents (bioherbicides) [1]-[7]. With regard to the development of herbicide resistance in weeds, for example, in 1996 there were no reports of weed species resistant to the herbicide glyphosate in the United States, but currently 24 weeds are documented as resistant to this compound and 218 species of weeds have become resistant to various herbicides in 61 countries [8].

Sesbania exaltata (Raf.) Rydb. ex A.W. Hill (hemp sesbania), is avigorous, nodulating leguminous weed in soybean [Glycine max (L.) Merr.], cotton (Gossypium hirsutum L.) and rice (Oryza sativa L.), often reaching heights of $3 \mathrm{~m}$ at maturity [9]. Hemp sesbania ranks as one of the 10 most troublesome weeds in the three southern US states of Arkansas, Louisiana, and Mississippi [10], reducing crop yield by shading and competition [11]. Hemp sesbania is also a prolific seed producer, yielding up to 21,000 seed per plant [12] and can reduce quality and market value due to black seed contamination in harvest rice grain.

Populations of 0.8 to 12.9 hemp sesbania plants $\mathrm{m}^{-2}$ emerging with soybean reduced the yield of wide-row (1 $\mathrm{m})$ soybeans by $10 \%$ to $80 \%$ when allowed to interfere throughout the growing season [13]. Emergence of the weed is characterized as quasi-simultaneous, therefore, if a dense crop canopy is not formed soon after application of a post-emergence herbicide that lacks residual control, weed re-infestation will likely occur [12].

Previous research has shown that conidial formulations of the bioherbicidal fungus Colletotrichum truncatum (Schw.) Andrus \& Moore are effective in controlling hemp sesbania under greenhouse and field conditions [14] [15] [16]. Solid substrates such as membranes, vermiculite and rice hulls, as well as liquid culture have been used to produce C. truncatum conidia [17]. Furthermore, Silman and Nelsen [18] and Jackson and Schisler [19] studied optimization of liquid culture media producing C. truncatum conidia. Various factors such as additives, $\mathrm{pH}$ and temperature can affect germination and virulence of $C$. truncatum, as well as the addition of other bioherbicidal pathogens, such as C. gloeosporioides in order to control two weeds: hemp sesbania and sicklepod [Senna obtusifolia (L.) Barnaby] [20] [21].

In addition to producing mycelium (hyphae) and conidia in solid and liquid culture, C. truncatum can also be induced to produce structures called microsclerotia (compact, dense aggregates of darkly pigmented, thickwalled hyphal cells) that can remain dormant for long periods until conditions favorable for growth occur [22]. C. truncatum microsclerotia can be produced in submerged liquid culture and stored in diatomaceous earth [19]. Dried microsclerotia formulated with pre-gelatinized corn flour and pre-gelatinized cornstarch prompted disease development in emerging hemp sesbania seedlings [23]. When conditions are favorable $\left(22^{\circ} \mathrm{C}\right.$ to $28^{\circ} \mathrm{C}$, moist soil), C. truncatum microsclerotia can "germinate" and form actively growing mycelia and conidia that infect stems and root surface cells of hemp sesbania, or directly invade roots through naturally occurring wounds [24]. Pre-emergence soil application of a microsclerotia/diatomaceous earth formulation has been reported to infect and kill hemp sesbania seedlings under growth chamber conditions [24]. Dried microsclerotia, formulated with pre-gelatinized corn flour and pre-gelatinized cornstarch, also prompted disease development in emerging hemp sesbania seedlings [19].

Several mycoherbicidal products applied to the soil before or during planting, or to emerging plants, have shown efficacy towards various species of weeds [25]-[28]. In order to effectively control weeds with a bioherbicide, the biological agent must be highly active and stable during storage. A long shelf-life resulted when $C$. truncatum microsclerotia were encapsulated in granules made with wheat flour and kaolin clay ("Pesta") [29]. High stability was achieved after one year storage at $25^{\circ} \mathrm{C}$ when a minimum of 7 microsclerotia $\mathrm{ml}^{-1}$ were en- 
capsulated in this matrix. C. truncatum microsclerotia formulated in "Pesta" stored at $4^{\circ} \mathrm{C}$ for 10 years remained highly viable and virulent [28].

Traditionally, the use of various cereal grains has been used as solid substrates for propagation of plant pathogenic fungi. Previous research in our laboratory demonstrated that several bioherbicidal fungi (Fusarium, Alternaria and Myrothecium isolates), cultured on cereal grains such as rice and corn, produced efficacious fungal-grain bioherbicidal products with relatively long shelf-life [30]-[32]. This inexpensive and minimalist process prompted us to examine the feasibility of applying this to the bioherbicidal fungus, $C$. truncatum. The objectives of the present study were to produce and test pre- and post-emergence applications of a $C$. truncatum-rice microsclerotial formulation for hemp sesbania control under greenhouse and field conditions and to evaluate efficacy under several environmental conditions.

\section{Materials and Methods}

\subsection{Culture and Maintenance}

A single-spore strain of C. truncatum (NRRL No. 18434) previously isolated from infected hemp sesbania colled near Stoneville, MS, USA [14] was used in all experiments. The fungus, which had been preserved in screw-capped tubes containing sterilized soil [33], was grown for 5 to 7 days on potato dextrose agar (PDA, Difco Laboratories, Detroit, MI, USA) in $10 \mathrm{~cm}$ plastic Petridishes. Dishes were incubated on open-mesh wireshelves in an incubator (Precision Scientific Inc., Chicago, IL, USA) at $25^{\circ} \mathrm{C}$ illuminated with cool, white fluorescent lighting (12 h photoperiod). C. truncatum spores were harvested by rinsing the cultures with water and straining through double-layered cheesecloth. Spore densities were determined with hemacytometers and dilutions were made in sterile, distilled water to inoculate the solid substrate (rice grain).

\subsection{Inoculum Production on Solid Substrate (Rice Grain)}

Long-grain, converted, enriched rice (Mars Food, Greenville, MS, USA) (200 g) was mixed with 120 ml distilled $\mathrm{H}_{2} \mathrm{O}$ in 1-L flasks and allowed to stand for about $1 \mathrm{~h}$, until the water was absorbed. Flasks were stoppered with cotton plugs and autoclaved $60 \mathrm{~min}$. After cooling, the flasks were shaken to break rice clumps. Then flasks were allowed to stand on a laboratory bench for $24 \mathrm{~h}$, and reautoclaved, vigorously shaken again and cooled to $20^{\circ} \mathrm{C}-22^{\circ} \mathrm{C}$. The flasks containing the sterilized rice grains were inoculated with $C$. truncatum spores $(10 \mathrm{ml}$, $2.0 \times 10^{7}$ spores $\mathrm{ml}^{-1}$ ) and incubated 3 to 4 weeks at $22^{\circ} \mathrm{C}$ with a 12 -h photoperiod (approximately 200 $\left.\mu \mathrm{mol} \cdot \mathrm{m}^{-2} \cdot \mathrm{s}^{-1}, \mathrm{PAR}\right)$. Daily shaking of the flasks for the first several days assured uniform distribution, penetration and incorporation of the fungus into the rice grains. At the end of the incubation period, the fungal-rice mixtures in the flasks were pooled, spread into screened bottomed trays and air dried. Dried samples were ground to a flour-like consistency (30 to 60 mesh) using a mill grinder (Stein Mill, Model M-2; F. Stein Laboratories, Inc., Atchison, KS, USA) housed in a biosafety cabinet. This ground powder (hereafter referred to as "product"),containing about $2.4 \times 10^{5}$ microsclerotia $\mathrm{g}^{-1}$, was used immediately or stored in plastic freezer bags at $4^{\circ} \mathrm{C}-5^{\circ} \mathrm{C}$ until further use.

\subsection{Viability of $C$. truncatum Microsclerotia Granules}

To test the viability of the ground C. truncatum-infested rice product, random samples (ca $0.1 \mathrm{~g}$ each) from pooled inocula were placed on filter paper (moistened with sterile distilled water) contained in plastic petri dishes (100 mm dia.) and incubated for $24 \mathrm{~h}$ at $25^{\circ} \mathrm{C}$ under a light regime of $12 \mathrm{~h} / 12 \mathrm{~h}$ (dark/light). This incubation period allowed microsclerotia to germinate and produce spores. Following incubation, the microsclerotia were visually examined under a stereo-light microscope (10× magnification) for evidence of fungal growth (spores and hyphae). Individual microsclerotia (50 to 60) were observed at various intervals (12 to $72 \mathrm{~h}$ ) and scored as "germinated" or "non-germinated". This procedure was performed in triplicate and repeated over time.

\subsection{Greenhouse Experiments}

Hemp sesbania seeds (Azlin Seed Co., Leland, MS, USA) were planted in a commercial potting mix (Jiffy-Mix; Jiffy Products of America, Batavia, IL, USA) contained in peat strips. Each strip contained uniform 12 plants. The potting mix was supplemented with a controlled-release (14:14:14, NPK) fertilizer (Osmocote; Grace Sierra Horticultural Products, Milpitas, CA, USA). The plants were placed in sub-irrigated trays on greenhouse ben- 
ches. Greenhouse temperatures ranged from $25^{\circ} \mathrm{C}$ to $30^{\circ} \mathrm{C}$ with $40 \%$ to $90 \%$ relative humidity (RH) and a $14 \mathrm{~h}$ photoperiod at 1800 PAR as measured at midday with a light meter. In the first greenhouse experiment, the fungus was applied using two application protocols as follows: 1) pre-emergence treatment using freshly-ground

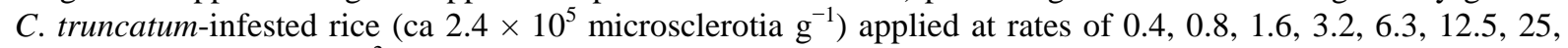
and $50 \mathrm{mg}$ per pot $\left(25 \mathrm{~cm}^{2}\right)$, and 2) post-emergence spray application using rates equivalent to the pre-emergence test. In a second greenhouse experiment, a post-emergence spray treatment (rate equivalent of $50 \mathrm{mg}$ per pot as in the pre-emergence treatment) was applied to plants surviving the pre-emergence treatment, 15 days later when surviving plants were in the 3 to 5 leaf growth stage.

All post-emergence fungal preparations were formulated in an aqueous emulsion of $30 \%$ unrefined corn oil (Spectrums Naturals, Petaluma, CA, USA) and 0.2\% Silwet L-77 surfactant (EMCO Chemical Distributors, Inc., Pleasant Prairie, WI, USA). Hemp sesbania seedlings were in the cotyledonary-first true leaf growth stages. Controls consisted of: equivalent amounts of autoclaved, ground rice (containing no fungus) applied pre- and post-emergence, 30\% unrefined corn oil and surfactant, and untreated plants. Spray applications (approximately

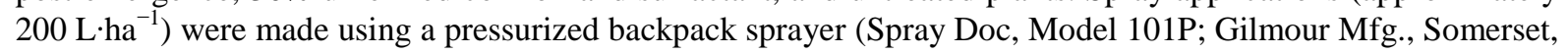
PA, USA). Following pre-, post-, and pre- plus post-treatments, seedlings were placed on greenhouse benches. For the greenhouse experiments percent control (mortality) was determined 15 days after treatment. Treatments were replicated four times, for a total of 48 individual plants per treatment. The experiments were repeated over time, and data were averaged following Bartlett's test for homogeneity of variance [34]. A randomized complete block experimental design was utilized.

\subsection{Field Experiments}

Field studies on a Dundee very fine sandy loam (Aeric Ochracualf) were conducted to test the efficacy of this bioherbicide-rice formulation at Stoneville, MS, USA, in 1998, 1999, and 2000. A set of field experiments utilized fungal treatments only at the high rate (50 mg per $25 \mathrm{~cm}^{2} ; 2.4 \times 10^{5}$ microsclerotia $\mathrm{cm}^{-2}$ ) in pre-, post- and pre-followed by post-emergence treatments. The rate of $50 \mathrm{mg} \cdot \mathrm{cm}^{-2}$ was chosen due to its high efficacy in greenhouse studies and because field results with bioherbicides may not always corroborate greenhouse findings. This rate and plants surviving the pre-emergence application were post-treated 15 days after the pre-emergence application. As in the greenhouse experiments all post-emergence fungal preparations were formulated in an aqueous emulsion of 30\% unrefined corn oil and $0.2 \%$ Silwet L-77 surfactant. During each year, the field experiments were conducted at four different 30-day periods representing four distinct environmental regimes. The four hemp sesbania seed field planting dates were: 1) early season (mid-April to mid-May), 2) early-mid season (mid-June to mid-July), 3) late-mid season (mid-July to mid-August), and 4) late season (mid-September to mid-October). The test plots, consisting of $32 \times 32 \mathrm{~cm}$ micro-plots $\left(1.0 \times 10^{-5} \mathrm{ha}\right)$, were planted with mechanically-scarified hemp sesbania seed (Azlin Seed Co., Leland, MS, USA) at a density of 300 seed plot $^{-1}$. The plots were irrigated (by hand) until fully wetted to a $5 \mathrm{~cm}$ depth prior to planting and pre-emergence applications, and thereafter with a hand sprinkler as necessary to promote and maintain vigorous plant growth. Surviving hemp sesbania plants (3- to 5-leaf growth stage) were treated 15 days after pre-emergence applications were made. All spray applications were made with hand-held pump sprayers as described for the greenhouse experiments at spray rates of $200 \mathrm{~L} \cdot \mathrm{ha}^{-1}$. Surviving plants (3- to 5-leaf growth stage) were treated 15 days after the pre-emergence applications. Mortality evaluations in the field studies were made at 15 days for the pre- plus post-treatment, and at 30 days after planting for the pre-emergence only treatment, and the post-treatment only.

\subsection{Experimental Design and Statistics}

All experiments were arranged as randomized complete block designs with four replications. All experiments were repeated over time, and data were averaged following Bartlett's test for homogeneity of variance [34]. Data were statistically compared using analysis of variance (ANOVA). Values are presented as the means of replicated experiments. In the microsclerotia studies and the inoculum concentration tests in the greenhouse and field. Data were also subjected to "best-fit curve" regression analysis.

\section{Results and Discussion}

\subsection{Viability of $C$. truncatum Microscclerotia Granules}

C. truncatum microsclerotia began to "germinate" and fungal growth (spores and mycelium) was observed 8 to 
$10 \mathrm{~h}$ after the ground product was placed on moistened filter paper and incubated at $25^{\circ} \mathrm{C}$ (data not shown). Fungal growth (conidia and mycelia) was visually evident after $12 \mathrm{~h}$ (Figure 1) and propagule viability (microsclerotia germination) in tests of these granules exceeded $90 \%$ by 60 to $72 \mathrm{~h}$ after hydration (Figure 2). Similar results from previousstudies with conidia of $C$. truncatum formulated in "Pesta" granules showed that conidia were produced for at least 10 days, yielding a cumulative total of $10^{8}$ conidia gram $^{-1}$ of formulated product [35].

\subsection{Greenhouse Results}

The $C$. truncatum-rice formulation, applied pre-emergence at rates of $0.4,0.8,1.6,3.2,6.3,12.5,25$, and $50 \mathrm{mg}$ finely-ground fungus-rice product to $5 \mathrm{~cm}^{2}$ of soil surface, caused $22 \%, 46 \%, 55 \%, 68 \%, 72 \%, 93 \%$, $96 \%$, and 96\% hemp sesbania plant mortality, respectively, at 14 days after treatment (Figure 3). The post-emergence spray treatment, utilizing pre-emergence rate equivalent fungus-rice concentrations, resulted in $20 \%, 45 \%, 50 \%$, $63 \%$, $80 \%, 84 \%$, and $93 \%$ weed mortality, respectively (Figure 3). A post-emergence treatment of weeds sur-

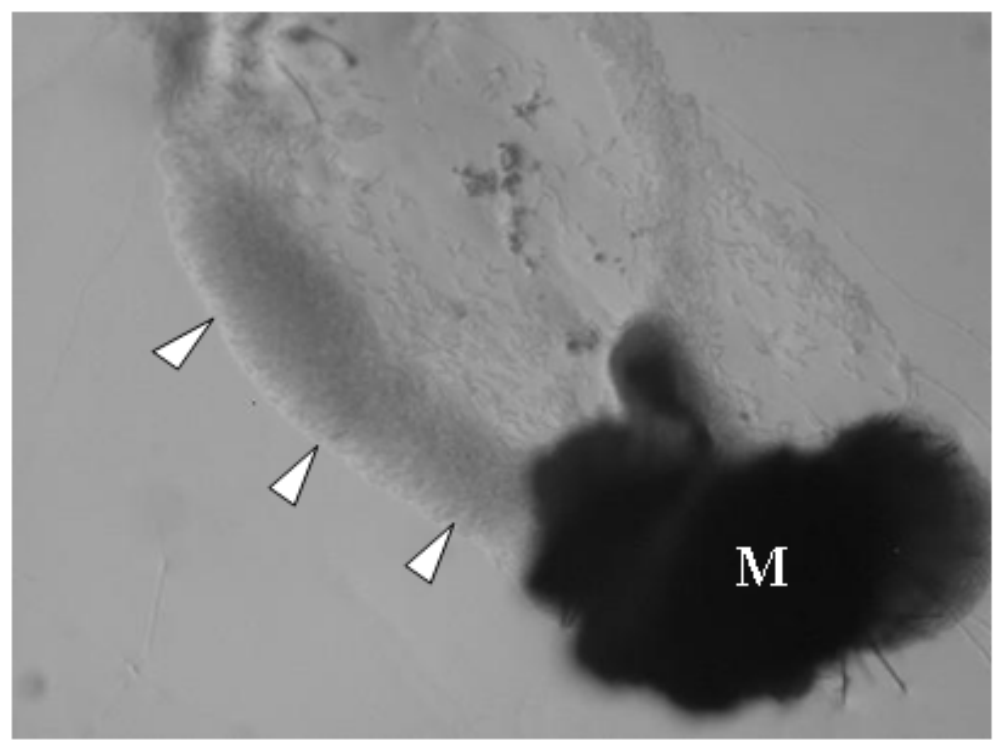

Figure 1. C. truncatum microsclerotium (M) releasing spores (depicted by white arrowheads). Fungal growth (conidia and mycelia) was visually evident after $24 \mathrm{~h}$.

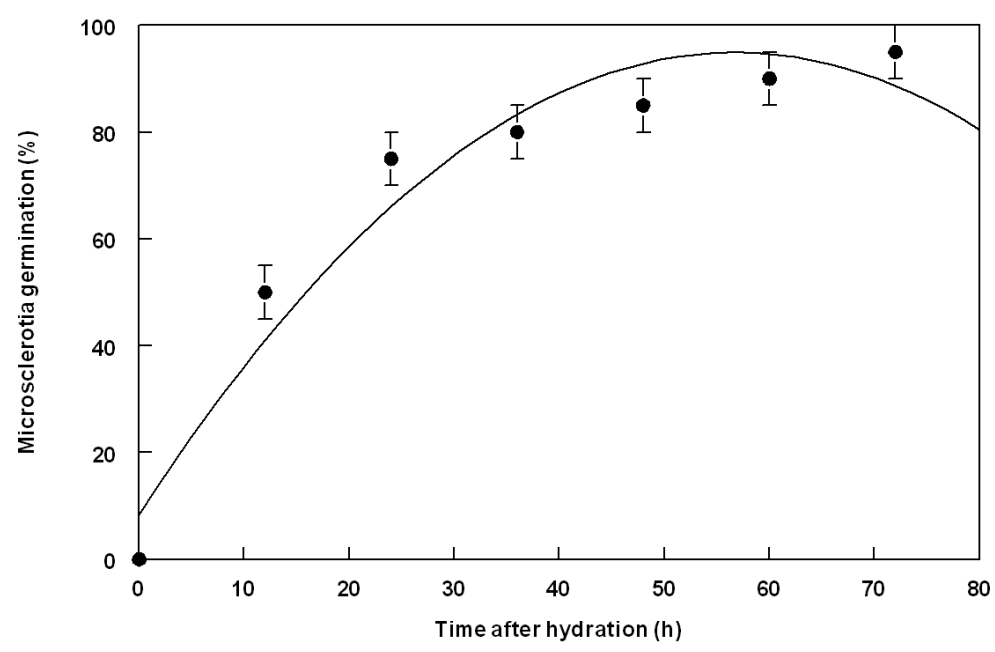

Figure 2. Propagule viability in ground fungus-rice product at various times after hydration and incubation at $25^{\circ} \mathrm{C}$ in petri dishes. 
viving this pre-emergence application, caused an average of 99\% mortality 14 days after treatment (Table 1). It is noteworthy that the plants were not subjected to a free-moisture (dew) period, thus corroborating our findings in previous research that certain adjuvants, such as unrefined corn oil, can supplant the requirements for a dew period [36].

\subsection{Field Results}

Due to similarities of the data over the three years of testing, only data from 1999 is presented. Environmental conditions varied within the four testing periods (Table 2). Over the field testing season, the early season (April

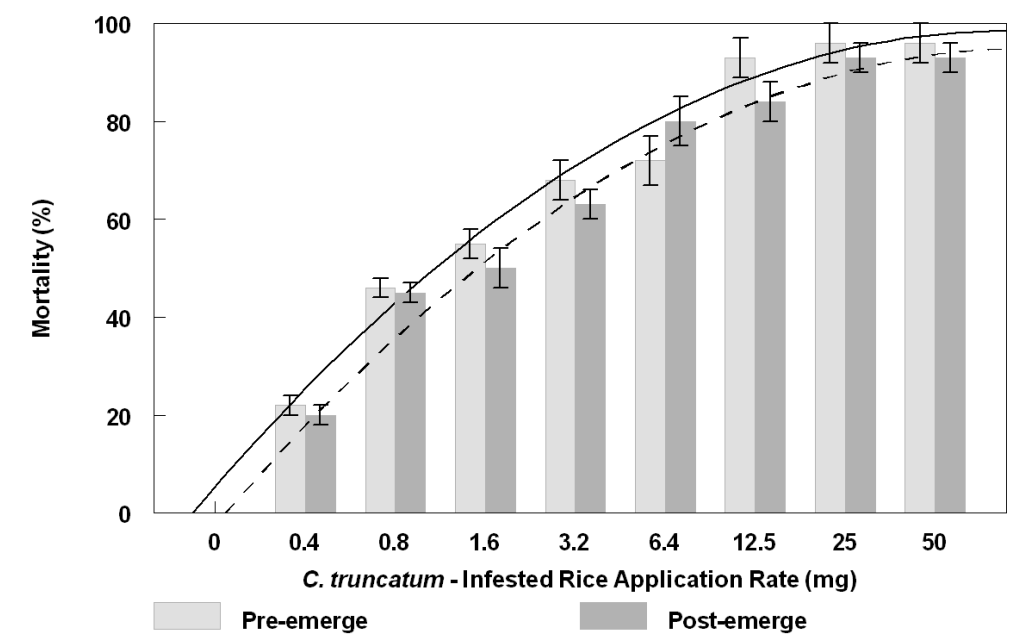

Figure 3. Hemp sesbania control as affected by dose response of pre- and post-applications of $C$. truncatum-rice formulation in the greenhouse. Error bars of the histograms represent \pm 1 S.E.M. The dose response curves (solid line $=$ pre-emergence; dashed line $=$ post-emergence) are best represented by the equations: (pre-emergence). $\mathrm{Y}=-31.00+32.77 \times-2.11 \mathrm{X}^{2} ; \mathrm{R}^{2}=0.97$; (post-emergence) $\mathrm{Y}=-20.16+22.84 \times-1.13 \mathrm{X}^{2} ; \mathrm{R}^{2}=0.98$, where $\mathrm{X}=$ dose rate and $\mathrm{Y}=$ mortality. Control treatments: pre-emergent test $=$ ground product sans fungus; post-emergence treatment $=30 \%$ unrefined corn oil, $0.2 \%$ Silwet in water.

Table 1. Biological control of hemp sesbania with C. truncatum microsclerotia under greenhouse conditions, 14 days after treatment.

\begin{tabular}{|c|c|c|}
\hline Treatment & Mortality1 & Survival \\
\hline \multicolumn{3}{|l|}{ Pre-emergence } \\
\hline Control (autoclaved rice sans fungus) & $0 \mathrm{c}$ & $100 \mathrm{a}$ \\
\hline C. truncatum-infested rice & $78 \mathrm{~b}$ & $22 \mathrm{~b}$ \\
\hline \multicolumn{3}{|l|}{ Post-emergence } \\
\hline Control (30\% corn oil + $0.2 \%$ Silwet) & $0 \mathrm{c}$ & $100 \mathrm{a}$ \\
\hline C. truncatum-infested rice & 99 a & $1 \mathrm{c}$ \\
\hline \multicolumn{3}{|l|}{ Pre-followed by post-emergence } \\
\hline \multicolumn{3}{|c|}{ Control (Pre- = rice product sans fungus) plus } \\
\hline (Post- $=30 \%$ corn oil $+0.2 \%$ Silwet $)$ & $0 \mathrm{c}$ & $100 \mathrm{a}$ \\
\hline \multicolumn{3}{|l|}{ C. truncatum-fungus-rice in $30 \%$} \\
\hline corn oil $+0.2 \%$ surfactant $)$ & 99 a & $1 \mathrm{c}$ \\
\hline
\end{tabular}

\footnotetext{
${ }^{1}$ Values within columns followed by the same letter are not significantly different at $\mathrm{P}=0.05$ according to Fisher's protected LSD.
} 
Table 2. Environmental conditions during the 1999 bioherbicidal field testing periods at Stoneville, MS.

\begin{tabular}{ccccccccccc}
\hline \multirow{2}{*}{ Test period } & \multicolumn{3}{c}{ Temp. $\left({ }^{\circ} \mathrm{C}\right)$} & \multicolumn{2}{c}{ RH (\%) } & \multicolumn{2}{c}{ Precipitation $(\mathrm{cm})$} \\
\hline & Air & \multicolumn{3}{c}{ Soil } \\
& Max & Min & Max & Min & Max & Min & Total & Avg. \\
\hline Early (April 15-May 15) & 26.7 & 14.9 & 28.6 & 17.7 & 93.8 & 43.6 & 16.31 & 0.53 \\
Early-mid (June 15-July 15) & 31.7 & 21.7 & 36.8 & 25.7 & 96.4 & 54.6 & 7.54 & 0.25 \\
Late-mid (July 15-Aug. 15) & 35.5 & 23 & 41.8 & 28.7 & 96.4 & 47.2 & 1.02 & 0.05 \\
Late (Sept. 15-Oct 15) & 29.1 & 13.1 & 31.4 & 18.0 & 94.7 & 35.7 & 4.06 & 0.13 \\
\hline
\end{tabular}

to May), pre-emergence treatment provided 67\% mortality of hemp sesbania at 15 days, and the post-emergence treatment caused 91\% mortality of the surviving weeds (Figure 4). Results were similar in the early-mid-season (June to July), with 73\%, 93, and 98\% mortality of weeds occurring in the pre-emergence, post-emergence, and pre- plus post-emergence treatments, respectively (Figure 5). Figure 6 depicts surviving plants and dead plants as affected by the highest concentration of rice-fungus applied. However, in the late-mid-season (July to August), pre-emergence treatment caused only about $2 \%$ mortality within 15 days, while post-emergence treatment controlled $75 \%$, and pre- plus post-emergence treatments controlled $80 \%$ of hemp sesbania (Figure 7). The relatively high soil and air temperatures recorded during this period may have had a detrimental effect upon disease development. Results from the late-season (September to October) treatments were similar to those recorded in the early season April to May) (Figure 8).

These results show that temperature, rainfall, and/or planting date play an important role in the efficacy of a $C$. truncatum-infested rice formulation when applied pre-emergence or post-emergence to hemp sesbania plants. Furthermore, this rice grain (solid substrate) bioherbicide formulation can control hemp sesbania using preemergence and post-emergence applications, especially during moderate temperatures and adequate moisture provided in the early and early-mid seasons.

The present study has demonstrated the successful use of soil applications of microsclerotia of the bioherbicide Colletotrichum truncatum formulated on rice grain to effectively control hemp sesbania. Although most bioherbicide research studies have focused on the use of pathogens that promote disease above the soil surface [4], significant progress has been achieved using soilborne pathogens as bioherbicides [4] [7] [27] [37] [38]. For soilborne bioherbicides, short-term fluctuations in environmental conditions, such as soil moisture and temperature are less critical because the soil may act as a buffer to resist rapid environmental changes often encountered above ground [39]. Rainfall amounts and the timing of dew application can cause differential effects on disease severity and weed control of a bioherbicide to its target weed. For example, simulated rainfall tests showed that moderate or heavy rainfall had little effect on disease development and control of hemp sesbania with $C$. truncatum, but the effect of timely dew application exhibited a greater role on these parameters [40]. Crop canopy closure, crop and weed densities and row spacing are also import factors in affecting disease development and bioherbicide efficacy as demonstrated by use C. truncatum on hemp sesbania and C. gloeosporioides on another leguminous weed, sicklepod [21] [41]. In the present studies, during the early-mid period, significant rainfall occurred shortly after planting (and pre-emergence treatment) and during the 15 day period prior to the post- emergence treatment where $7.7 \mathrm{~cm}$ of rain was recorded (Figure 6). After the post-emergence treatment, a total of only $1.3 \mathrm{~cm}$ of rainfall occurred, but most $(1.2 \mathrm{~cm})$ occurred on the day that data were recorded. Adequate moisture (dew, rainfall or irrigation water) can promote germination of microsclerotia with subsequent spore release, and production of humongous numbers (up to $10^{8}$ spores per microsclerotium). Since spores (not microsclerotia) are the infective units, high inoculum potential is achieved and high weed control efficacy is attained.

Another consideration regarding the present studies is the possibility of induced resistance when plant hosts are subjected to sub-lethal doses of a phytopathogen [42] [43]. Some hemp sesbania plants survived exposure to C. truncatum during the pre-emergence treatment, but $99 \%-100 \%$ of the surviving plants were killed by application of $C$. truncatum during the post-emergence treatment with the fungus. This suggests that either induction was not caused by the pre-emergence exposure or that the high concentration of microsclerotia (spores) applied 


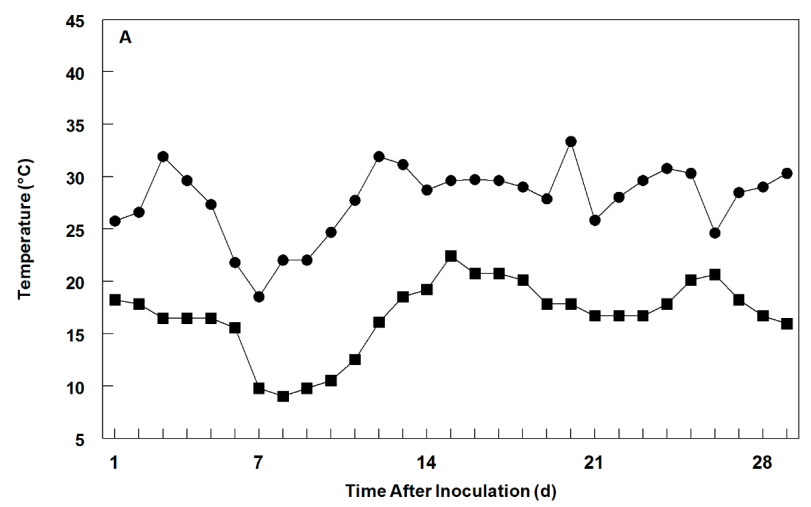

(a)

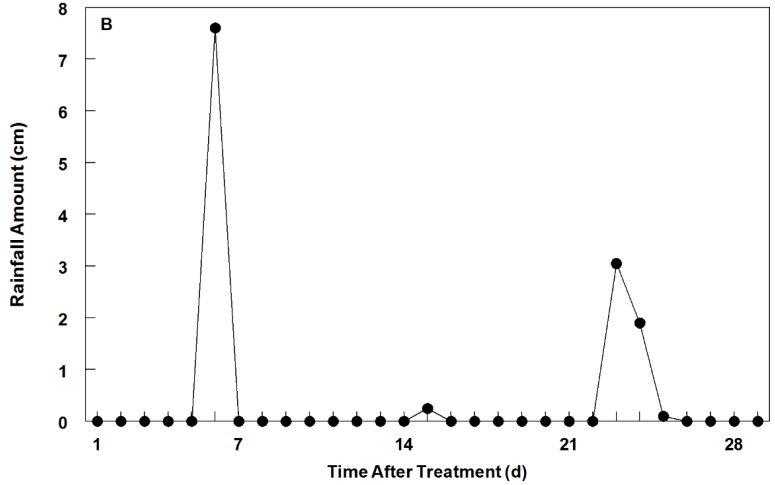

(b)

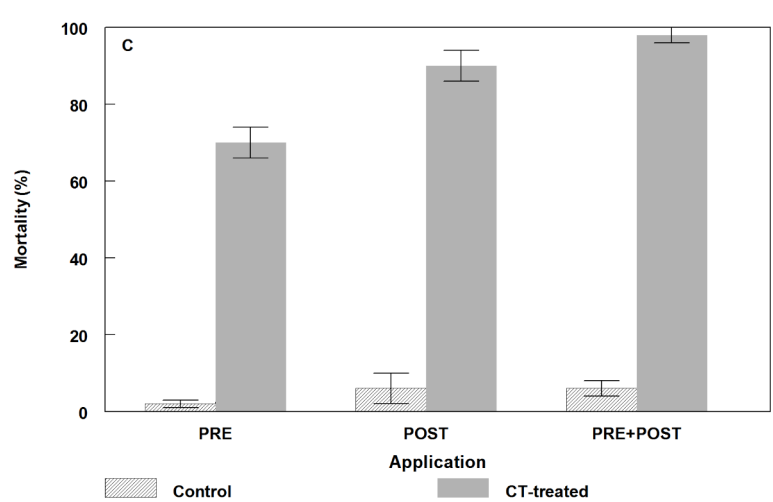

(c)

Figure 4. Hemp sesbania control in the field by C. truncatum-rice formulation applied pre-, post-, and pre- plus post-emergence. Error bars are Fisher's protected LSD values at the 0.05 level of probability. Environmental parameters [(a) $=$ soil temperature (minimum = solid squares; maximum = solid circles) and (b) = rainfall] during early-season (April to May) are presented on a daily basis. Mortality data (c) were recorded 15 days after treatment. Control treatments: pre-emergent test = ground product sans fungus; post-emergence treatment $=30 \%$ unrefined corn oil, $0.2 \%$ Silwet in water.

during post-emergence treatment, overwhelmed or masked any incidence of induced resistance. Although these experiments were not designed to test induction of resistance this would be an important topic of future research.

Prior to the isolation of this fungal isolate (NRRL 18434) from hemp sesbania, several different C. truncatum isolates had been shown to be causal agents of soybean anthracnose [44] [45]. Host range specificity studies of NRRL 18434 spore formulations for possible effects on various crop and weed species showed that, of the 12 weeds from 6 families tested, infectivity only occurred on hemp sesbania. Further, no infectivity occurred on about 12 crops, including major crops such as corn, rice, and cotton [14]. That report also examined 9 soybean cultivars and found 6 were not infected, but there was some minimal infection to 3 cultivars and "Bragg” soybean was the most susceptible. What was also reported was a comparative study of NRRL 18434 with other $C$. truncatum (NRRL 15933 and ATCC 18013) and C. dematium (ATCC 22852) isolates on "Bragg” soybean that indicated NRRL 18434 and NRRL 15933 had low infectivity, but ATCC 22852 and ATCC 18013 had high to severe effects on this crop cultivar. Since certain soybean cultivars may be slightly susceptible to NRRL 18434, it would be prudent to test any cultivar for sensitivity to this bioherbicide prior to field applications.

Other recent uses of fungal microsclerotia have been reported. Microsclerotia of an insecticidal fungus Metarhizium spp., produced from submerged liquid culture fermentation followed by mixing with diatomaceous earth, yielded a dried granule formulation that was tolerant to desiccation and was stable for 3.5 months [46]. Yields of microsclerotia ranged from $6.1-7.3 \times 10^{6} \mathrm{~L}^{-1}$ after 3 days growth with maximum yields $\left(0.7-1.1 \times 10^{7} \mathrm{~L}^{-1}\right)$ after 5 days growth. These granules of microsclerotia and diatomaceous earth have potential to control certain soil-inhabiting insects [47] [48] and mass production and stabilization has been achieved [49]. Liquid culture production of microsclerotia of the phytopathological fungus Mycoleptodiscus terrestris, a potential biological control agent for the management of Hydrilla has also been reported [50]. 


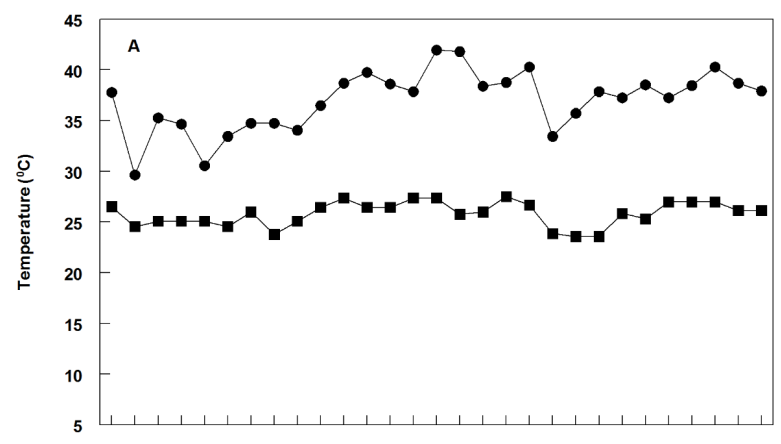

(a)

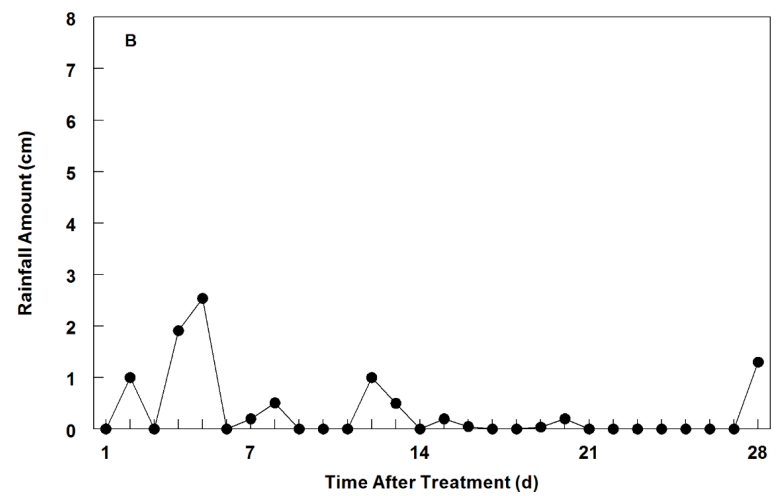

(b)

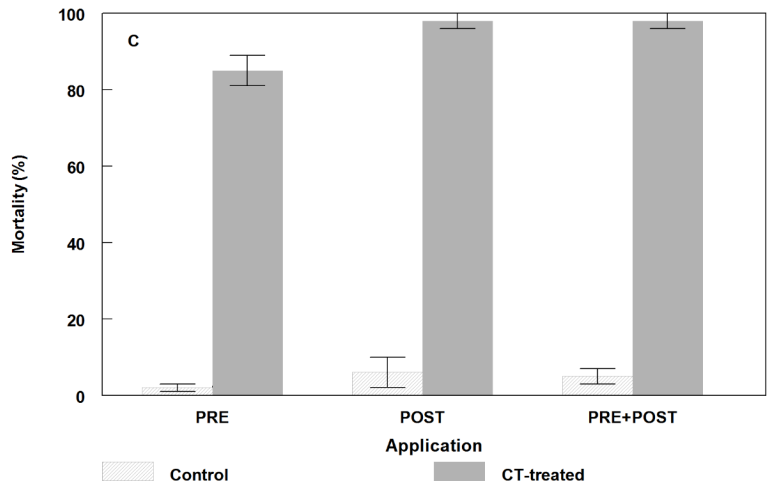

(c)

Figure 5. Hemp sesbania control in the field by C. truncatum-rice formulation applied pre-, post-, and pre- plus post-emergence. Error bars are Fisher's protected LSD values at the 0.05 level of probability. Environmental parameters [(a) = soil temperature (minimum = solid squares; maximum = solid circles) and (b) = rainfall] during early-mid-season (June to July) are presented on a daily basis. Mortality data (c) were recorded 15 days after treatment. Control treatments: pre-emergent test $=$ ground product sans fungus; post-emergence treatment $=30 \%$ unrefined corn oil, $0.2 \%$ Silwet in water.

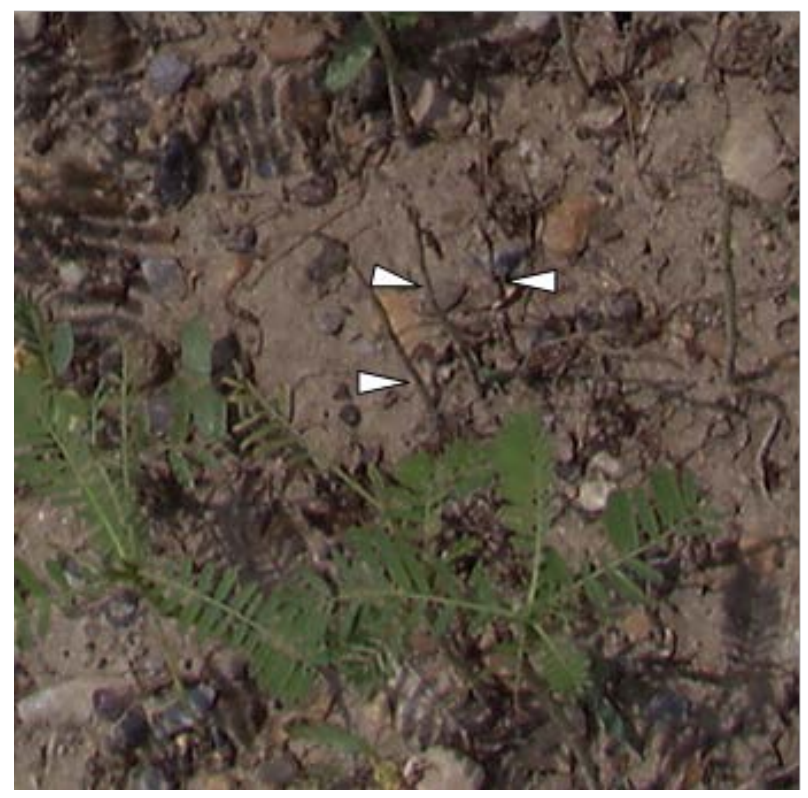

Figure 6. Hemp sesbania infected and killed (white arrowheads) by C. truncatum-rice formulation post-emergence spray application at $50 \mathrm{mg}$ per $25 \mathrm{~cm}^{2}$. Surviving plants shown at bottom of photo were untreated. 


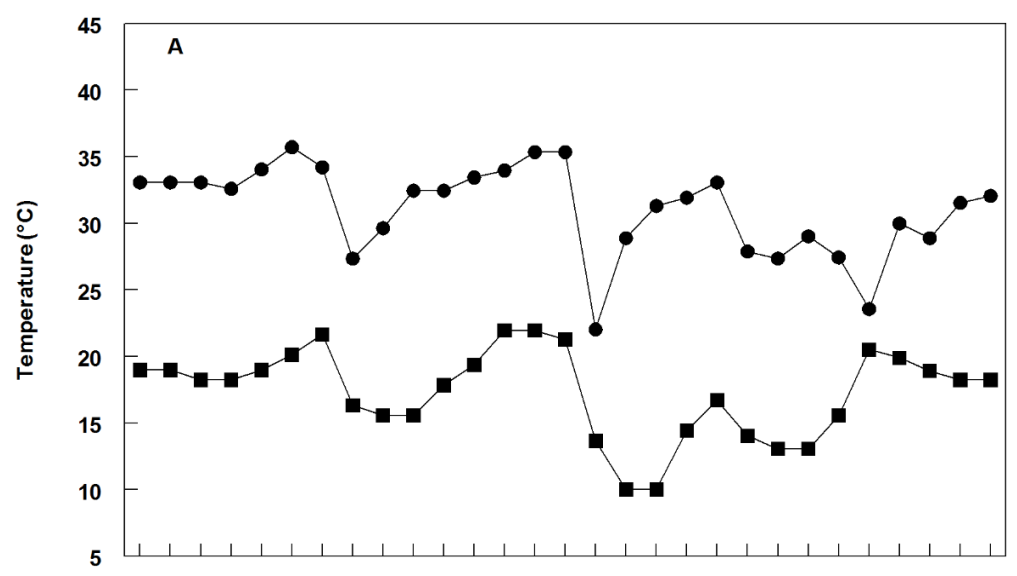

(a)

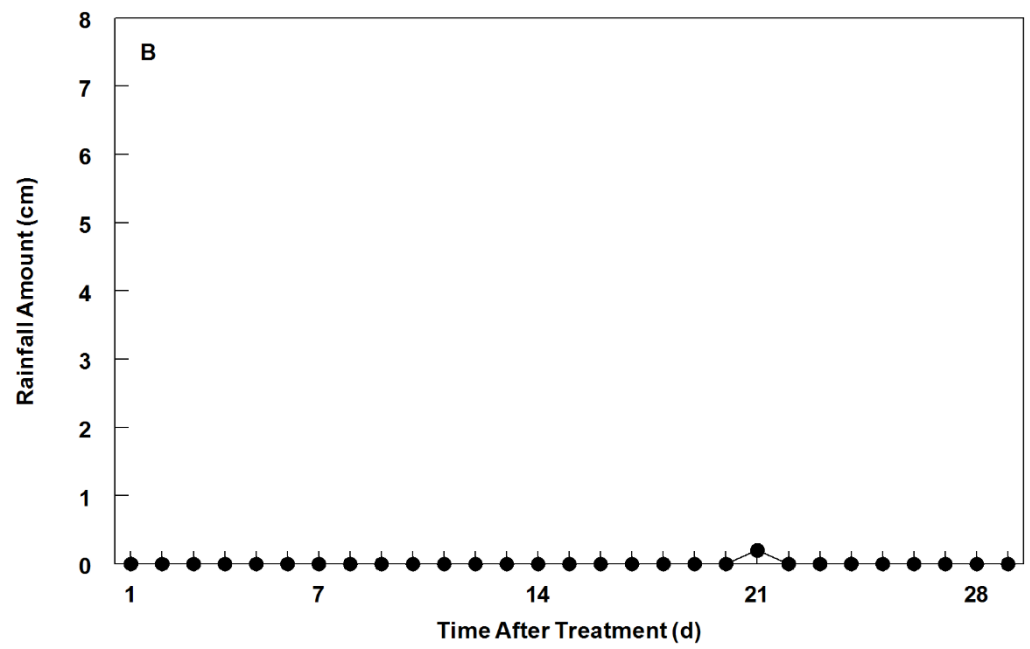

(b)

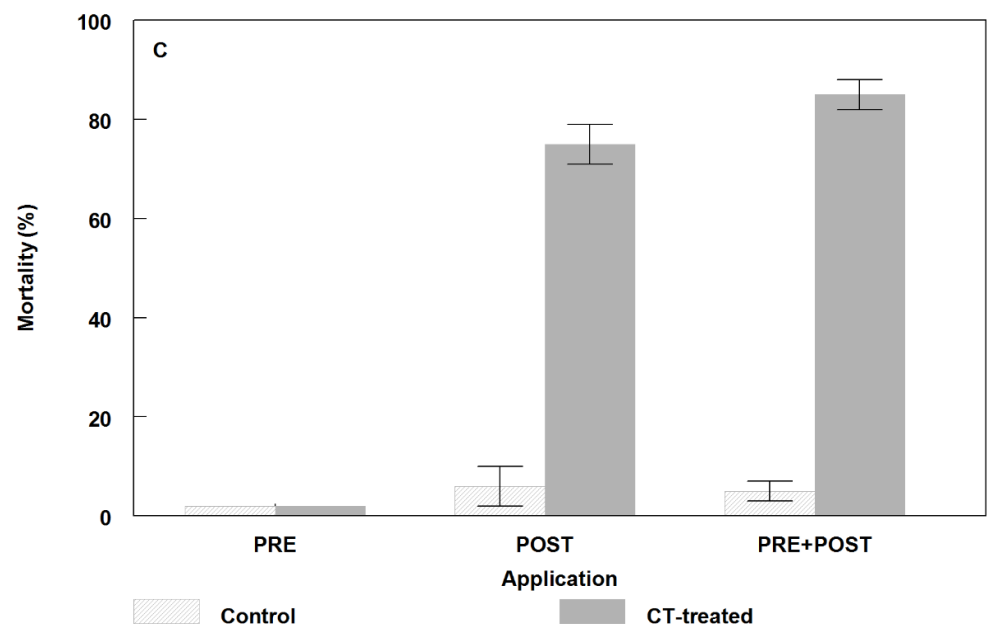

(c)

Figure 7. Hemp sesbania control in the field by C. truncatum-rice formulation applied pre-, post-, and pre- plus post-emergence. Error bars are Fisher's protected LSD values at the 0.05 level of probability. Environmental parameters [(a) $=$ soil temperature (minimum = solid squares; maximum = solid circles) and (b) = rainfall] during late-mid-season (July to August) are presented on a daily basis. Mortality data (c) were recorded 15 days after treatment. Control treatments: pre-emergent test $=$ ground product sans fungus; post-emergence treatment $=30 \%$ unrefined corn oil, $0.2 \%$ Silwet in water. 


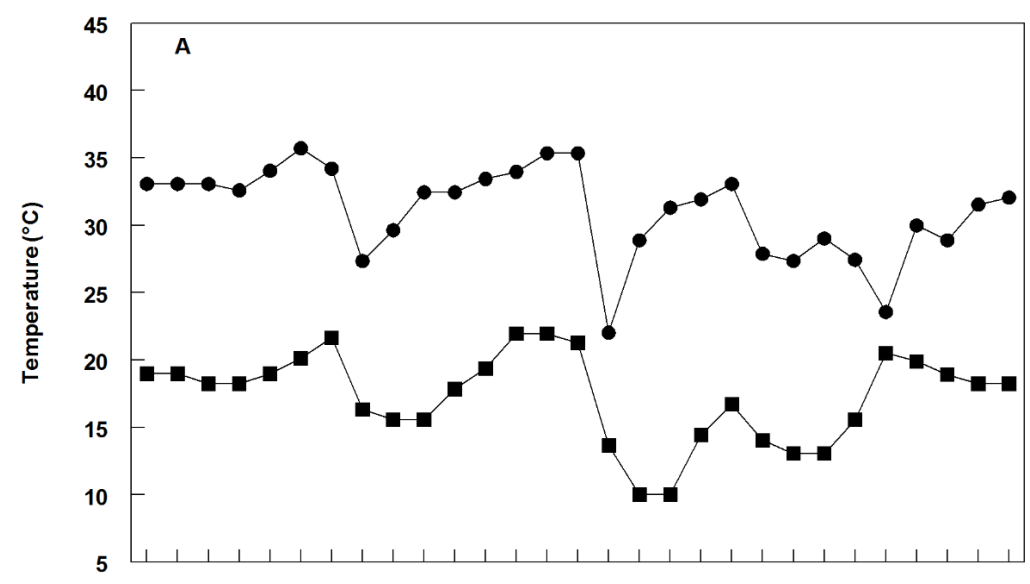

(a)

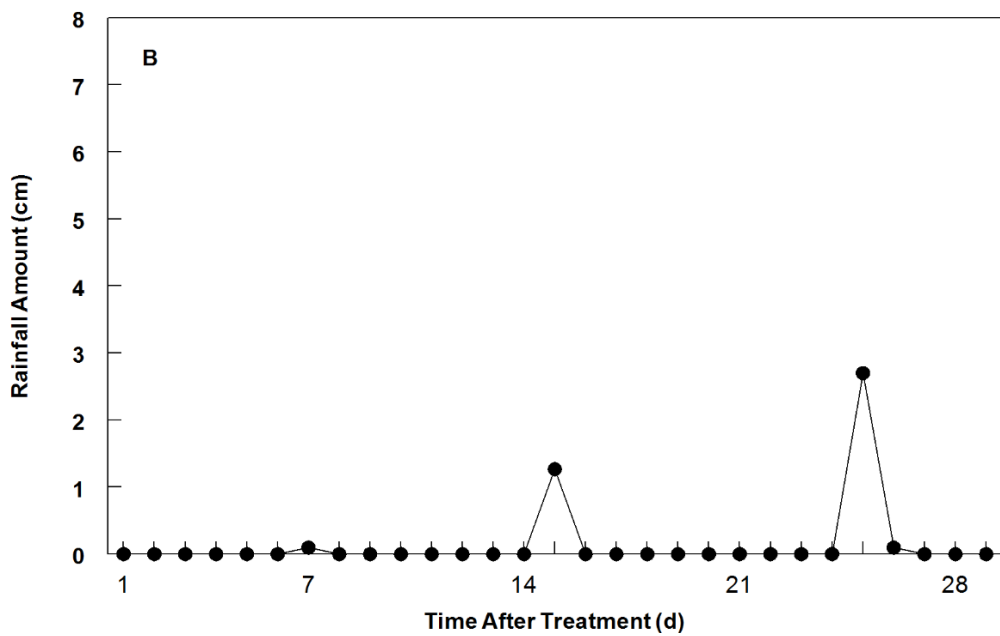

(b)

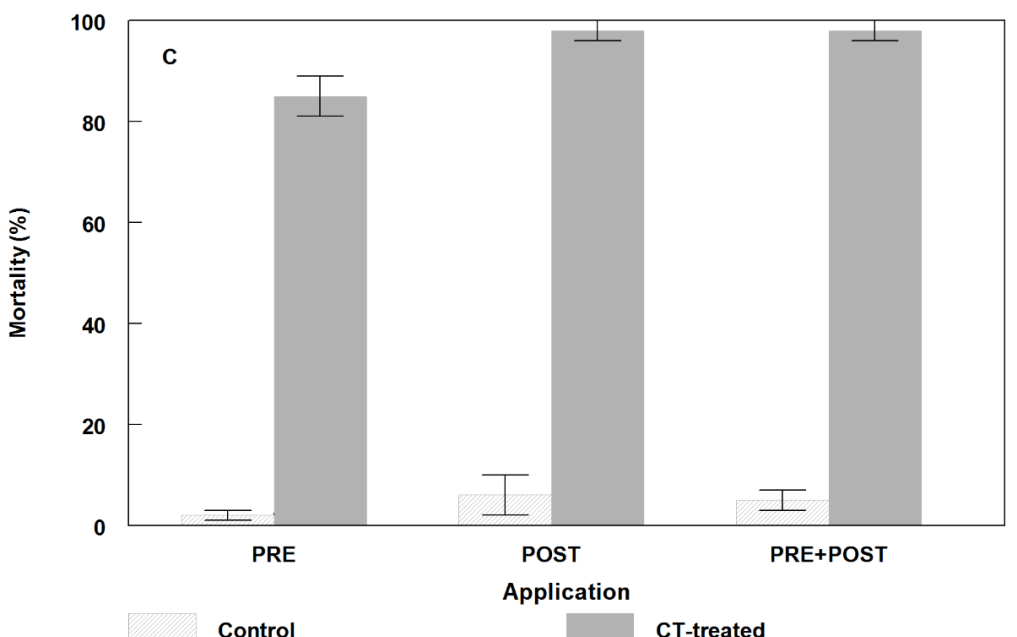

(c)

Figure 8. Hemp sesbania control in the field by C. truncatum-rice formulation applied pre-, post-, and pre- plus post-emergence. Error bars are Fisher's protected LSD values at the 0.05 level of probability. Environmental parameters $[(a)=$ soil temperature (minimum = solid squares; maximum = solid circles) and (b) = rainfall] during late-season (September to October) are presented on a daily basis. Mortality data (c) were recorded 15 days after treatment. Control treatment for preemergent test $=$ ground product sans fungus, and $30 \%$ unrefined corn oil, $0.2 \%$ Silwet in water for post-emergence treatment . 
The versatility of $C$. truncatum to control hemp sesbania with fungal spores in liquid carrier adjuvants, or on solid substrates containing spores, microsclerotia, or mycelial fragments, suggests that other bioherbicidal fungal pathogens may also possess the capability of "multi-propagule" production. Application of this concept to other bioherbicidal candidates may make them more attractive for commercial development through advances in solid state fermentation technologies.

\section{Acknowledgements}

The authors wish to thank Robin H. Jordan for assistance of the graphic presentation of this data.

\section{References}

[1] Hoagland, R.E. (1990) Microbes and Microbial Products as Herbicides. American Chemical Society, Washington DC. http://dx.doi.org/10.1021/bk-1990-0439

[2] TeBeest, D.O. (1991) Microbial Control of Weeds. Chapman and Hall, New York. http://dx.doi.org/10.1007/978-1-4615-9680-6

[3] Rosskopf, E.N., Charudattan, R. and Kadir, J.B. (1999) Use of Plant Pathogens in Weed Control. In: Bellows, T.S. and Fisher, T.W., Eds., Handbook of Biological Control, Academic Press, New York, 891-918. http://dx.doi.org/10.1016/B978-012257305-7/50082-5

[4] Charudattan, R. (2001) Biological Control of Weeds by Means of Plant Pathogens: Significance for Integrated Weed Management in Modern Agro-Ecology. BioControl, 46, 229-260. http://dx.doi.org/10.1023/A:1011477531101

[5] Charudattan, R. (2005) Ecological, Practical, and Political Inputs into Selection of Weed Targets: What Makes a Good Biological Control Target? Biological Control, 35, 183-196. http://dx.doi.org/10.1016/j.biocontrol.2005.07.009

[6] Hallett, S.G. (2005) Where Are the Bioherbicides? Weed Science, 53, 404-415. http://dx.doi.org/10.1614/WS-04-157R2

[7] Weaver, M.A., Lyn, M.E., Boyette, C.D. and Hoagland, R.E. (2007) Bioherbicides for Weed Control. In: Updhyaya, M.K. and Blackshaw, R.E., Eds., Non-Chemical Weed Management, CABI, International, Cambridge, 93-110.

[8] Heap, I. (2014) International Survey of Herbicide-Resistant Weeds. http://www.weedscience.org/in.asp

[9] Lorenzi, H.J. and Jeffery, L.S. (1987) Weeds of the United States and Their Control. Van Nostrand Reinhold, New York.

[10] Dowler, C.C. (1997) Weed Survey-Southern States. Proceedings of the Southern Weed Science Society, 45, $392-407$.

[11] King, C.A. and Purcell, L.C. (1997) Interference between Hemp Sesbania (Sesbania exaltata) and Soybean (Glycine max) in Response to Irrigation and Nitrogen. Weed Science, 45, 91-97.

[12] Lovelace, M.L. and Oliver, L.R. (2000) Effects of Interference and Tillage on Hemp Sesbania and Pitted Morningglory Emergence, Growth, and Seed Production. Proceedings of the Southern Weed Science Society, 53, 202.

[13] McWhorter, C.G. and Anderson, J.M. (1979) Hemp sesbania (Sesbania exaltata) Competition in Soybeans (Glycine max). Weed Science, 27, 58-64.

[14] Boyette, C.D. (1991) Host Range and Virulence of Colletotrichum truncatum, a Potential Mycoherbicide for Hemp sesbania (Sesbania exaltata). Plant Disease, 75, 62-64. http://dx.doi.org/10.1094/PD-75-0062

[15] Boyette, C.D., Quimby Jr., P.C., Bryson, C.T., Egley, G.H. and Fulgham, F.E. (1993) Biological Control of Hemp Sesbania (Sesbania exaltata) under Field Conditions with Colletotrichum truncatum Formulated in an Invert Emulsion. Weed Science, 41, 497-500.

[16] Boyette, C.D., Hoagland, R.E. and Weaver, M.A. (2007) Biocontrol Efficacy of Colletotrichum truncatum for Hemp Sesbania (Sesbania exaltata) Control Is Enhanced with Unrefined Corn Oil and Surfactants. Weed Biology and Management, 7, 70-76. http://dx.doi.org/10.1111/j.1445-6664.2006.00230.x

[17] Silman, R.W., Nelsen, T.C. and Bothast, R.J. (1991) Comparison of Culture Methods for Production of Colletotrichum truncatum Spores for Use as a Mycoherbicide. FEMS Microbiology Letters, 79, 69-74. http://dx.doi.org/10.1111/j.1574-6968.1991.tb04507.x

[18] Silman, R.W. and Nelsen, T.C. (1993) Optimization of Liquid Culture Medium for Commercial Production of Colletotrichum truncatum. FEMS Microbiology Letters, 107, 273-278. http://dx.doi.org/10.1111/j.1574-6968.1993.tb06042.x

[19] Jackson, M.A. and Schisler, D.A. (1995) Liquid Culture Production of Microsclerotia of Colletotrichum truncatum for Use as Bioherbicidal Propagates. Mycological Research, 99, 879-884. http://dx.doi.org/10.1016/S0953-7562(09)80745-4

[20] Boyette, C.D. and Hoagland, R.E. (2012) Interactions of Chemical Additives, pH and Temperature on Conidia Germi- 
nation and Virulence of Colletotrichum truncatum, a Bioherbicide for Sesbania exaltata. Allelopathy Journal, 30, 102116.

[21] Boyette, C.D. and Hoagland, R.E. (2010) Biological Control of Hemp Sesbania (Sebania exaltata) and Sicklepod (Senna obtusifolia) in Soybean with Anthracnose Pathogen Mixtures. Weed Technology, 24, 551-556. http://dx.doi.org/10.1614/WT-08-154.1

[22] Agrios, G.N. (1988) Plant Pathology. 3rd Edition, Academic Press, Inc., New York.

[23] Jackson, M.A., Shasha, B.S. and Schisler, D.A. (1996) Formulation of Colletotrichum truncatum Microsclerotia for Improved Biocontrol of the Weed Hemp Sesbania (Sesbania exaltata). Biological Control, 7, 107-113. http://dx.doi.org/10.1006/bcon.1996.0072

[24] Schisler, D.A. and Jackson, M.A. (1996) Germination of Soil-Incorporated Microsclerotia of Colletotrichum truncatum and Colonization of Seedlings of the Weed Sesbania exaltata. Canadian Journal of Microbiology, 42, 1032-1038. http://dx.doi.org/10.1139/m96-132

[25] Boyette, C.D., Templeton, G.E. and Oliver, L.R. (1984) Texas Gourd (Cucurbita texana) Control with Fusarium solani f. sp. cucurbitae. Weed Science, 32, 497-501.

[26] Boyette, C.D. and Walker, H.L. (1986) Evaluation of Fusarium lateritium as a Biological Herbicide for Controlling Velvetleaf (Abutilontheophrasti) and Prickly Sida (Sidaspinosa). Weed Science, 34, 106-109.

[27] Abbas, H.K. and Boyette, C.D. (2000) Solid Substrate Formulation of the Mycoherbicide Colletotrichum truncatum for Hemp Sesbania (Sesbania exaltata) Control. Biocontrol Science and Technology, 10, 291-300. http://dx.doi.org/10.1080/09583150050044565

[28] Boyette, C.D., Jackson, M.A., Bryson, C.T., Hoagland, R.E., Connick, W.J. and Daigle, D.J. (2007) Sesbania exaltata Biocontrol with Colletotrichum truncatum Microsclerotia Formulated in "Pesta” Granules. BioControl, 52, 413-426. http://dx.doi.org/10.1007/s10526-006-9031-7

[29] Connick Jr., W.J., Jackson, M.A., Williams K.S. and Boyette, C.D. (1997) Stability of Microsclerotial Inoculum of Colletotrichum truncatum Encapsulated in Wheat Flour-Kaolin Granules. World Journal of Microbiology and Biotechnology, 13, 549-554. http://dx.doi.org/10.1023/A:1018517409756

[30] Abbas, H.K., Boyette, C.D., Hoagland, R.E. and Vesonder, R.F. (1991) Bioherbicidal Potential of Fusarium moniliforme and Its Phytotoxin, Fumonisin. Weed Science, 39, 673-677.

[31] Abbas, H.K. and Boyette, C.D. (1992) Phytotoxicity of Fumonisin B1 on Weed and Crop Species. Weed Technology, 6, 548-552.

[32] Hoagland, R.E., Boyette, C.D. and Abbas, H.K. (2007) Myrothecium verrucaria Isolates and Formulations as Bioherbicide Agents for Kudzu. Biocontrol Science and Technology, 17, 721-731. http://dx.doi.org/10.1080/09583150701527268

[33] Bakerspigel, A. (1953) Soils as a Storage for Fungi. Mycologia 45, 596-604.

[34] Steele, R.G.D., Torrey, J.H. and Dickeys, D.A. (1997) Multiple Comparisons. Principles and Procedures of StatisticsA Biometrical Approach. McGraw Hill, New York.

[35] Connick Jr., W.J., Boyette, C.D. and McAlpine, J.R. (1992) Formulation of Mycoherbicides Using a Pasta-Like Process. Biological Control, 1, 281-287. http://dx.doi.org/10.1016/1049-9644(91)90079-F

[36] Boyette, C.D. (1994) Unrefined Corn Oil Improves the Mycoherbicidal Activity of Colletotrichum truncatum for Hemp Sesbania (Sesbania exaltata) Control. Weed Technology, 8, 526-528.

[37] Weidemann, G.J. and Templeton, G.E. (1988) Control of Texas Gourd, Cucurbita texana, with Fusarium solani f. sp. cucurbitae. Weed Technology, 2, 271-274.

[38] Boyette, C.D., Bryson, C.T. and Hoagland, R.E. (2011) Biological Control of Cucurbita pepo var. Texana (Texas Gourd) in Cotton (Gossypium hirsutum) with the Fungus Fusarium solani f. sp. cucurbitae. Pest Technology, 5, 97101.

[39] Weidemann, G.J., Boyette, C.D. and Templeton, G.E. (1995) Utilization Criteria for Mycoherbicides. In: Hall, F.R. and Barry, J.W., Eds., Biorational Pest Control Agents: Formulation and Delivery, American Chemical Society, Washington DC, 238-251. http://dx.doi.org/10.1021/bk-1995-0595.ch018

[40] Boyette, C.D., Bryson, C.T., Hoagland, R.E. and Weaver, M.A. (2012) Effects of Simulated Rainfall on Disease Development and Weed Control of the Bioherbicidal Fungi Alternaria cassiae and Colletotrichum truncatum. Weed Technology, 26, 117-121. http://dx.doi.org/10.1614/WT-D-10-00127.1

[41] Boyette, C.D., Hoagland, R.E. and Weaver, M.A. (2007) Effect of Row Spacing on Biological Control of Sicklepod (Senna obtusifolia) with Colletotrichum gloeosporioides. Biocontrol Science and Technology, 17, 957-967. http://dx.doi.org/10.1080/09583150701553157 
[42] Kuc, J. (1983) Induced Resistance in Plants to Diseases Caused by Fungi and Bacteria. In: Bailey, J.A. and Deverall, B.J., Eds., The Dynamics of Host Defense, Academic Press, London, 146-170.

[43] Walters, D., Walsh, D., Newton, A. and Lyon, G. (2005) Induced Resistance for Plant Disease Control: Maximizing the Efficacy of Resistance Elicitors. Phytopathology, 95, 1368-1373. http://dx.doi.org/10.1094/PHYTO-95-1368

[44] Tiffany, L.H. (1951) Delayed Sporulation of Colletotrichum on Soybean. Phytopathology, 41, 975-985.

[45] Sinclair, J.B. (1982) Compendium of Soybean Diseases. 2nd Edition, American Phytopathological Society, Saint Paul, $104 \mathrm{p}$.

[46] Mascarin, G.M., Kobori, N.N., Vital, R.C., Jackson, M.A. and Quintela, E.D. (2014) Production of Microsclerotia by Brazilian Strains of Metarhizium spp. Using Submerged Liquid Culture Fermentation. World Journal of Microbiology and Biotechnology, 30, 1583-1590. http://dx.doi.org/10.1007/s11274-013-1581-0

[47] Jackson, M.A. and Jaronski, S.T. (2009) Production of Microsclerotia of the Fungal Entomopathogen Metarhizium anisopliae and Their Potential for Use as a Biocontrol Agent for Soil-Inhabiting Insects. Mycological Research, 113, 842-850. http://dx.doi.org/10.1016/j.mycres.2009.03.004

[48] Behle, R.W., Jackson, M.A. and Flor-Weiler, L. (2013) Efficacy of a Granular Formulation Containing Metarhizium brunneum F52 (Hypocreales: Clavicipitaceae) Microsclerotia against Nymphs of Ixodes scapularis (Acari: Ixoididae). Journal of Economic Entomology, 106, 57-63. http://dx.doi.org/10.1603/EC12226

[49] Jaronski, S.T. and Jackson, M.A. (2008) Efficacy of Metarhizium anisopliae Microsclerotial Granules. Biocontrol Science and Technology, 18, 849-863. http://dx.doi.org/10.1080/09583150802381144

[50] Shearer, J.F. and Jackson, M.A. (2006) Liquid Culturing of Microsclerotia of Mycoleptodiscus terrestris, a Potential Biological Control Agent for the Management of Hydrilla. Biological Control, 38, 298-306. http://dx.doi.org/10.1016/j.biocontrol.2006.04.012 
Scientific Research Publishing (SCIRP) is one of the largest Open Access journal publishers. It is currently publishing more than 200 open access, online, peer-reviewed journals covering a wide range of academic disciplines. SCIRP serves the worldwide academic communities and contributes to the progress and application of science with its publication.

Other selected journals from SCIRP are listed as below. Submit your manuscript to us via either submit@scirp.org or Online Submission Portal.
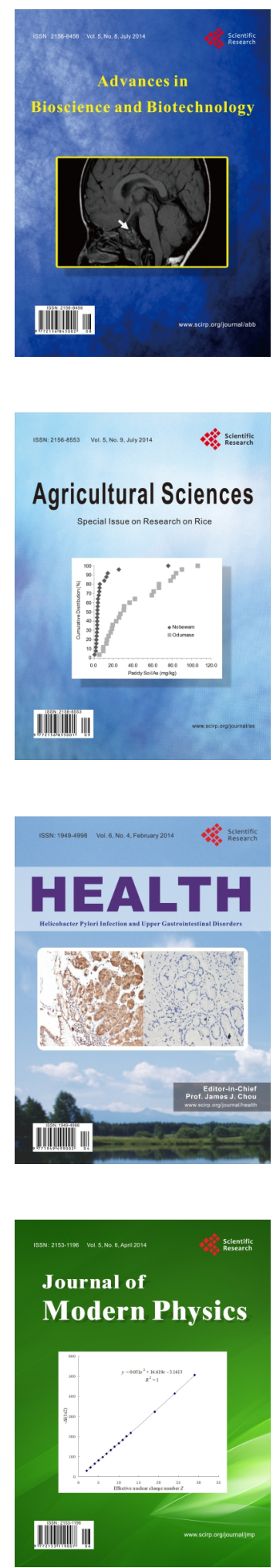
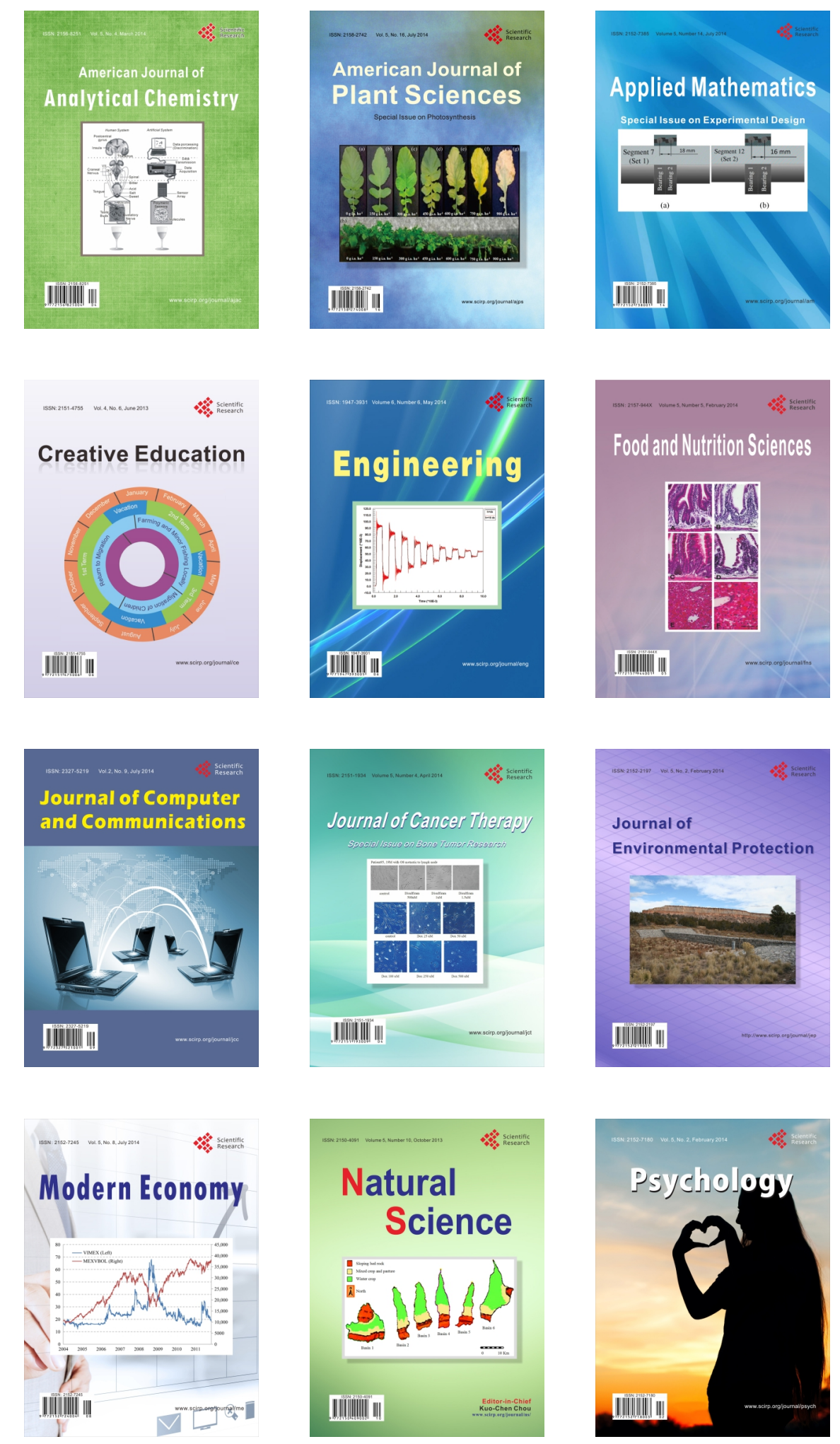